\title{
The strategy of slang words translation in "the kissing booth" movie subtitle
}

\author{
Lilik Istiqomah, Aulia Ilma Muyasaroh, Ika Lutfiana Muliawati \\ Institut Agama Islam Negeri (IAIN) Surakarta \\ mdcorp100@gmail.com
}

\begin{abstract}
This study sets out to describe the translation strategy and the impacts of the strategy to the accuracy and acceptability of slang words translation in "The Kissing Booth" movie subtitle. The research data were collected from "The Kissing Booth" movie file along with the subtitles, both in English and Indonesian. The data were all slang words found in "The Kissing Booth" movie dialogue and subtitle. This study employed descriptive qualitative method to analyze the slang words from the dialogue in the movie. The result of the research shows that the slang words found in the movie are divided into 8 (eight) categories which are: Euphemism with 4 (four) data, Dysphemism with 11 (eleven) data, Typical in Spoken Language with 8 (eight) data, Typical in Informal Situation with 11 (eleven) data, Metaphorical Utterance with 5 (five) data, Proverb with 2 (two) data, Untranslatability with 4 (four) data, and Neutral Syntactic Level with 5 (five) data.
\end{abstract}

Key words: slang, translation, strategy, movie.

\section{Introduction}

Slang is considered an independent non-literary language formation existing in a language formation existing in a language (Burdová, 2009:8). Ghil'ad Zuckermann (an Israeli Linguist) stated that "Slang refers to informal (and often transient) lexical items used by a specific social problem, for instance, teenagers, soldiers, missionaries, and thieves" (Zuckermann, 2003:21). Usually, Slang is used in daily conversation among teenagers but if the case is for soldiers or thieves, Slang is functioned as a secret code. As stated by Andersson and Trudgil (1990:87), Slang is always used selfconsciously with the desire to create a particular identity, that is why Slang changes its identity according to who is using. What is slang to one, may is not to another, depending on ones educational, economic or social position, and even according to location and generation. Slang also changes over time, and either disappears quickly.

Many new words have been emerged and formed by teenagers (Claire, 1998) such as what's up, lit, dammit, and so on. Nowadays, slang would often be found quite a lot in western movies, especially teenager's ones, because teenagers are the community who often use it. In this case, the authors examine slang words which existed in a teenager movie entitled "The Kissing Booth". The reason to why the author chose this movie to be analyzed is that this movie is quite popular among teenagers after it was released last May, year 2018 on
NETFLIX. Despite the fact that every teenagers are talking about the infamous Noah and Elle whenever they had a chance, it is highly doubted that they are able to understand the meaning behind all the slangs used in the movie. Translating slang words is not easy as translating any other words. Translator or subtitler should know the meaning deeply and surely, how and when slang words to be translated.

There are three functions of using slang (Yanchun and Yanhong, 2013). The first social function is the pursuit of self-identity, the second is to express emotive feeling of the users, and the third if to achieve politeness. For this reason, the authors wants to analyze the implementation of slang words and the accuracy between the real meaning and the subtitled slang words which existed in "The Kissing Booth" movie along with current issues that are happening in Indonesian communities, especially among teenagers. The aim of this research is to provide the readers with more extensive words to broaden the knowledge of how natives use slang in their conversation and to understand better about slang words. The researchers also found several slang words that are often used by young people in Indonesia such as Savage, Dude, Dammit, Chill, etc. This proves that some teenagers learn language through subtitles in films. 
The researchers focus on finding and analyzing slang words in the dialogue and subtitles of The Kissing Booth movie. This research is done with hope to change the negative stereotype about the difficulty of learning English, which is mostly considered as a frightening specter for some students in Indonesia. The authors wants to convey that learning English is a fun thing. Besides, just like a saying "kill two birds with one stone", we can be entertained by watching our favorite movies and we can also get knowledge from our entertainment by understanding what the meaning of the words are.

\section{Slang Words Translation in Movie}

Language has its laws and principles fixed yet it's a process of a free creation because as a matter of fact, the principles of generation used is completely free and infinitely varied. The interpretation, use of words, those involves a process of free creation as well since most of living individual in this world is one to desire for diversity and uniqueness in their life, so there are no bounds for everyone to create their own language as long as they do not break the laws and principles. The process of free creations furthermore produce a lot of ideas, meaning, or translation that occurred in surroundings, but it needs to be underlined that not every production of free creation can be understood or even accepted by the community. There has to be a process of transferring meaning from one set of language signs into another by observing the grammar and the use of dictionary so the process of translation can be involved. This statement is related in studying slang language as well because people in a society may speak various kind of language as the different social situation they encountered, so it is necessary to pay attention to the words by grammar, the rules of language, or the culture in order to understand and be able to transfer the meaning properly. People should be aware of what situation they are in, hence it is important to choose what language is appropriate to the situation. To be able to do that, people needs to look up the dictionary for the meaning and find out if there is by any chance the kind of slang which can be used in the situation. (Chomsky 1968; Holmes, 2001; and McGuire 1991:13.

Slang plays a significant role in the society, so it is not an astonishment for people to often use it. Slang even cut down and brought up to cinemas from movie directors into their works, especially movies with modern setting, with an intention to create such a natural environment to make audiences come to drift away with the storyline. The movies would appear more tangible and natural with inserted slang words in dialogues occurred along the plot.

Coleman (2004:2) notes that slang is usually short lived and often belongs to the specifics age or social clique. It is like fashion wheel, always roll over time to fulfill people's taste and tendency in some particular time, and it may revolve but often just rotate. Same goes to slang, although for these centuries they have been constantly developed, there has not been a single rotation yet in the use of slang through every century. It does not rule out the possibility though, for slang languages to rotate back to the former ones as it is a part of language that again, is a free creation process.

There are five periods of slang history according to Partridge (2004) from Random House Historical Dictionary of American Slang and from book "slang: Today and Yesterday", and each of them has different characteristics. The first time Slang appears was in the sixteenth century. At that time, slang was commonly used to change the inelegant statement of being associated with foreigner or criminal like in Patricos which means: Strolling, Doxies which means Beggar's trulls, and Priggers which means Thieves. Next, in the seventeenth century, Slang is developing into rich of figurative language and related to immoral action like word Clap which means Clatter, Crimp which means A game of card, and Buzzard which means A simpleton.

In the eighteenth century, Slang mostly used in comedy, for instance, in word Melt it means To spend, Tip means To lend, and Whiter-Go-Ye means A wife. Then in the nineteenth century, Slang rapidly grows and is started to be used for conversation in society such as word Bus which means A public carriage, Burra means A great man, and Burke means To kill. In the twentieth century, Slang becomes a part of spoken language not only used by criminals but also ordinary people like word Tanked which means Drunk, Cheero which means Classy, and Birdcage which means A person.

Furthermore, Partridge also clarified eleven types of slang according to his book, that are: Cockney Slang, Public House Slang, Workmen's Slang, Tradesmen's Slang, Slang in Art, Slang in Publicity, Slang in Theatre, Slang in Public School 
and University, Society Slang, Slang in Medicine, and Soldier's Slang.

The first type is Cockney Slang. This type of slang comes from End East of England and has a very pronounced accent. In the modern English, one clear example is alligator. (means: later). Second is Public House Slang, which is a public house group of words or phrases that makes up for the smallness of the recorded vocabulary by the nature of the subject. The example is booze-shunter (means: a beer drinker). And the third type is Workmen's Slang. This slang has a link with public house slang. The difference is the users of workmen's slang do not mention the real "something" but they call it with another name that already used and understood among them. Jumping Jinny (has meaning: a mechanical stamper used in road-repairs).

Fourth, we have Tradesmen's Slang. Some words are related to origin slang and the users are the workmen too. The difference is there are four typical users of tradesmen's slang: tailors, butchers, chemist, and builders. For tailors, they use house of parliament (means: a meeting of tailor's assistant and apprentices in the shop, especially for a serious purpose), and butchers use turkey buyer (a person of considerable important). Chemist use tamarinds which means money, and for builders, the use flannel jacket (means the navy work has so long and so unexceptionally worn flannel). Fifth is Slang in Art. which is still related to society. Words or phrases in this slang are quickly adopted by society and appears in seventeenth century when slang was brought in the stage for the first time in Richard Brome's comedy, A Fovial Crew. For example, the word Drawing (means: a picture in water-color).

Then, sixth is Slang in Publicity. This type of slang is often used for commence, because much of modern commerce depend on publicity, a firm needs the catchy phrase of rhymes that can impress the public. Example, worth a guinea a box (means: a small, cheap, yet good or useful article). The seventh is Slang in Theatre. Slang in this type is related with slang in art since theater is one of art term. Theater slang begins to develop in nineteenth centuries and expands its influence on ordinary and informal spoken English. The example is acting lady (means: an incapable actress).

Eight is Slang in Public School and University. The main source of this type is student, because they are fresh and full of creativity. Every school has its own special words known to no other school, while university students use slang to show who and from what university they are. One of slang in public school is Bung (means: a lie) while one in university is Black and Tame (means: an Oxford undergraduate). Nineth, Society Slang is commonly used in daily speaking and connected to the society. Every society group uses some types of slang, and by association, those words or phrase become property that belong to that group. The example is silver pheasant which means a beautiful society woman.

The tenth is Slang in Medicine. Medical slang is used by doctors and nurses. A little example by Ware is Lord have mercy (up) on me (means: the 'iliac passion', a 'colic' of the small guts). And finally the last one, is Soldier's Slang. This slang is terms that comes around the army community that is generally used by soldiers. Example, BOHICA (means: stand for bend over, here it comes again).

\section{Method}

In this research, the authors use a Qualitative Descriptive Method. Qualitative research is a research strategy that usually emphasizes words rather than quantification in the collection and analysis of data (Bryman 2008a:366). The authors focus on the description of a specific constituent in order to get the clear explanation about the research object. On this term, the authors try to analyze and describe the slang languages that are used in the movie "The Kissing Booth". The data source of this research is taken from the movie script The Kissing Booth, who was directed by Vince Marcello and based on a novel with the same name Beth Reekles. The film was released on May 2018 on Netflix, with the main data American Slang.

The subject of the research is the Kissing Booth movie. There were a few steps done by the authors in order to gather the data through observation and document analysis. The authors watching the movie for several times by using a set of computer in order to understand the entire storyline. Then, authors transcribed the subtitle of the movie into a written text in order to the data be easily recapped. In this study, the authors classify the data by using tables and description to analyze the data.

The procedure to collect data were: finding the slang expression in The Kissing Booth movie from the original script then the data were classified based on their characteristics. The number of words 
were 50 data. The data were classified into eight categories: Euphemism and Dysphemism, Typical of Spoken Language and Typical of Informal Situation, Metaphorical Utterance and Proverb, Untranslatable and Neutral Syntactic Level.

\section{Finding and discussion}

From "The Kissing Booth" movie, the authors find 50 slang words used in the movie dialogues through English subtitle and some of them are divided into eight categories based on their stylistic in translation. There are Euphemism and Dysphemism, Typical of Spoken Language and Typical of Informal Situation, Metaphorical Utterance and Proverb, Untranslatable and Neutral Syntactic Level.

First, there are Four data of Euphemism found in the English subtitle of "The Kissing Booth" movie; Douche, Douchebag, Dork, and Chill. Second, for Dysphemism there are eleven data; Asshat, Jackasses, Dick, Dammit, Kill it, this Shit, Wanker, Kick Ass, Holy Crap, Hell yeah, and Crushing it. Third, there are eight data in Typical of Spoken Language; Perv, Sesh, Def, Peeps, Bestie, Cutsies, Oh My Word, and As if. Fourth, there are eleven data in Typical of Informal Situation; Stupid Hot, MED, Knock it Off, Dude, Baller, Kiddo, Smooches, Hang out, Hookup, Shitting me, and Cheesy.

Fifth, there are five data in Metaphorical Utterance; Baby Steps, Sweet Mercy, Hit the Road, Killing it!, and Keep on Moving. Sixth, for Proverb there are two data; Cross my heart, and Nine gold diggers. Seventh, there are Untranslatability with four data; Seven Minutes in Heaven, Off-Limits!, Skinny Dipping, and What's Gucci. The last is a Neutral Syntactic Level with five data; BFF, Made Up, Crush, Catch, and Pretty Much.

\section{Euphemism}

It is a disclosure words refer to taboo or rough with finer words. One evidence of Euphemism in "The Kissing Booth" movie dialogue is Douche.

$\mathrm{EU} / 0536 / \mathrm{TKB} / 2018$

SL: Learning to be a better douche.

TL: Belajar untuk menjadi si brengsek yang lebih

baik.

In the Partridge's dictionary, Douche means a despicable person (1945). Then, the translator used "brengsek" as the translation of douche. "Brengsek" in Bahasa means a word to state someone who was being a bad person at some point. It is considered as a Euphemism because the insulting name is widely used in every suitable moment and the sound of it did not appear rude enough to be considered as a swearing word. Therefore, both translation of each dialogue has the same meaning.

\section{Dysphemism}

A literal opposite from Euphemism, Dysphemism is the substitution of a disagreeable, offensive, or disparaging expression for an agreeable or inoffensive one. One evidence of Dysphemism in "The Kissing Booth" movie dialogue is Dick.

\section{DY/1033/TKB/2018}

SL: and it always ended with me sounding like a

dick.

TL: dan selalu berakhir dengan aku terdengar seperti seorang bajingan.

Dick according to Partridge is a vulgar word for a penis. It is also an insulting thing to call someone who was rude, brash, or simply just being a really bad person towards someone else. The Indonesian translation is "Bajingan", which means a person, specifically a man with real bad attitude and it is quite harsh to say the word freely to someone else, hence, it is considered as a Dysphemism word. Therefore, both translation of each word has the same meaning.

\section{Typical in Spoken Language}

What is meant by spoken language here is that the words used will not be used in a written language since they emphasize on how to speak it quick but clear, so mostly the words are just an abbreviation of their intact word. One evidence of Spoken Language in "The Kissing Booth" movie dialogue is Perv.

$$
\begin{aligned}
& \text { SL/0406/TKB/2018 } \\
& \text { SL: Ew, Perv! } \\
& \text { TL: Ew, } \underline{\text { mesum! }} \\
& \text { In Partridge's dictionary, Perv is an }
\end{aligned}
$$
abbreviation of Pervy. This word is used for a person who is sexually perverted; pornographic (1944). The Indonesian translation of perv is "mesum which also means a person with dirty thoughts. It is considered 
as a Typical in Spoken Language since the word is not usual to be used in a written language for it is a kind of expression language. Therefore, the translation in both English and Indonesia has the correct meaning.

\section{Typical in Informal Situation}

This is a speech which is relaxed and friendly rather than serious, very correct, or official. One evidence of Informal Situation in "The Kissing Booth" movie dialogue is Dude.

\section{IS/1333/TKB/2018}

SL: I know, dude! Who saw that one coming?

TL: Aku tahu, kawan! Siapa yang menyangka hal itu akan terjadi?

According to Partridge's dictionary, dude used as a term of address, originally young male to male, but without regard to sex (1945), which is why in the movie, Elle, the main female character called her friend, Lee, with the word dude. The translator used "kawan" as the Indonesian translation, which means a regular fellow. It is considered as a Typical in Informal Situation because the word is inappropriate if it is used in formal occasion. Therefore, both the English and Indonesian translation of these words are suitable and correct.

\section{Metaphorical Utterance}

This is a figure of speech in which a term or phrase is applied to something to which it is not literally applicable in order to suggest a resemblance, as in a phrase Baby Steps. One evidence of Metaphorical Utterance in "The Kissing Booth" movie dialogue is Baby Steps.

MU/1351/TKB/2018

SL: Baby steps Elle. Baby steps.

TL: Pelan-pelan, Elle. Pelan-pelan.

Baby steps is an act that makes a very small amount of progress towards achieving something. The translator used a word "pelan-pelan" which is suitable with the word baby steps since it means slow down. Baby steps is considered as a metaphorical utterance because it compares initial stages of a new endeavor to the very small and stumbling steps of a child just learning to walk. Therefore, the translation in both English and Indonesian dialogue are acceptable.

\section{Proverb}

Is a simple, concrete, traditional saying that expresses a truth based on common sense or experience. One evidence of Proverb in "The Kissing Booth" movie dialogue is Cross my heart.

\section{PR/5835/TKB/2018 \\ SL: Cross my heart. \\ TL: Aku berjanji.}

In Partridge's dictionary, cross my heart is a catchphrase of declaration that one is telling the truth (mid 19-20th century). Then, the translator translated it into "aku berjanji" in Indonesia, which means that a person is sealing a sincerity and you can count on them. Cross my heart is considered as a proverb since it is a traditional saying that indeed express a truth based on common sense. Therefore, both translation of each dialogue has the similar meaning and can be accepted.

\section{Untranslatability}

Untranslatability is a property of any utterance in one language, for which no equivalent utterance can be found in another language when translated. One evidence of Untranslatability in "The Kissing Booth" movie dialogue is Seven Minutes in Heaven.

\section{UT/0325/TKB/2018 \\ SL: Played Seven Minutes in Heaven, Fail! \\ TL: Bermain Seven Minutes in Heaven, gagal!}

Seven minutes in heaven is a teenagers' party game where who people are selected to go into a closet or other dark enclosed space and do whatever they like for seven minutes. It is common for the participants to kiss, make out, have sex, and the others. The translator did not translate it into Indonesian because it might chance the entire meaning and essence of the matter. Hence, it is considered as an untranslatable word, yet still correct and acceptable because it stays the way it is to keep the original meaning.

\section{Neutral Syntactic Level}

It means that the slang is also applicable to a formal language. One evidence of Neutral Syntactic 
Level in "The Kissing Booth" movie dialogue is Crush.

NS/0334/TKB/2018

SL: Realized I had a crush on Noah.

TL: Menyadari aku naksir pada Noah.

According to Partridge's dictionary, Crush is a romanticized affection for someone (1884). The Indonesian translation of crush is "naksir" which means a feeling of admiration towards someone. It is considered as a Neutral Syntactic Level because the word is suitable and acceptable in both formal and informal occasion, therefore the translation in each dialogue has the same meaning.

Afterwards, the authors found 50 data that are included in the categories of slang. The data were divided into eight categories, which are; Euphemism, Dysphemism, Typical in Spoken Language, Typical in Informal Situation, Metaphorical Utterance, Proverb, Untranslatability, and Neutral Synttatic Level. The data were analyzed into some classification as illustrated in the table 1 :

\begin{tabular}{|c|c|c|c|c|}
\hline NO & $\begin{array}{c}\text { CATEGORIES OF } \\
\text { SLANG }\end{array}$ & FREQUENCY & PERCENTAGE & $\begin{array}{c}\text { NUMBER OF } \\
\text { DATA }\end{array}$ \\
\hline 1 & Euphemism & 4 & $8 \%$ & $\begin{array}{l}9,15,35,47 \\
8,11,16,20\end{array}$ \\
\hline 2 & Dysphemism & 11 & $22 \%$ & $\begin{array}{c}22,23,27,28 \\
42,43,48\end{array}$ \\
\hline 3 & $\begin{array}{l}\text { Typical in Spoken } \\
\text { Language }\end{array}$ & 8 & $16 \%$ & $\begin{array}{c}5,12,13,17 \\
30,32,36,40 \\
6,10,14,18\end{array}$ \\
\hline 4 & $\begin{array}{l}\text { Typical in Informal } \\
\text { Situation }\end{array}$ & 11 & $22 \%$ & $\begin{array}{c}21,26,37,39 \\
44,46,49\end{array}$ \\
\hline 5 & $\begin{array}{l}\text { Metaphorical } \\
\text { Utterance }\end{array}$ & 5 & $10 \%$ & $\begin{array}{c}19,24,25,34 \\
38\end{array}$ \\
\hline 6 & Proverb & 2 & $4 \%$ & 45,50 \\
\hline 7 & Untranslatability & 4 & $8 \%$ & $2,7,31,33$ \\
\hline 8 & $\begin{array}{l}\text { Neutral Syntactic } \\
\text { Level }\end{array}$ & 5 & $10 \%$ & $1,3,4,29,41$ \\
\hline Total & & 50 & $100 \%$ & 50 \\
\hline
\end{tabular}

Table 1. Translation strategy of slang

As stated in the table above, the authors found 50 slang words in the script of The Kissing Booth movie dialogue. The 50 data are further included in eight slang categories, namely Euphemism, Dysphemism, Typical in Spoken Language, Typical in Informal Situations, Metaphorical Utterance, Proverb, Untranslatable, and Neutral Syntactic Level. From each category, the authors found the highest and lowest number. In all eight categories, it was found that the highest number was Dysphemism and Typical in Informal Situation category i.e. 22\%, meanwhile the lowest was Proverb category with only $4 \%$. Then, in Euphemism and Neutral Syntactic Level categories the percentage is on $8 \%$, Typical in Spoken
Language with 16\%, and the last, Metaphorical Utterance and Neutral Syntactic Level on $10 \%$.

\section{Conclusion}

Slang word is a language which can be used in conversation among close friends, relatives, and acquaintances that some of them contains rude, crude, and sexual matters. After analyzing this research, the authors found some information such as the background of The Kissing Booth movie and the characteristics of slang in the movie that was divided into eight categories. The authors also found 49 slang word from the eight categories of slang in Kissing Booth movie. 
Based on this research result, there are 49 slang words in The Kissing Booth movie. The slang is divided into eight categories: 1) Four words in Euphemism, 2) Eleven words in Dysphemism, 3) Eight words in Typical in Spoken Language, 4) Eleven words in Typical in Informal Situation, 5) Five words in Metaphorical Utterance, 6) Two words in Proverb, 7) Four words in Untranslatability, and 8) Five words in Neutral Syntactic Level.

\section{Suggestion}

1. The authors suggest this title to another researcher who would want to continue this study into deeper analysis of this film, in the other aspect. The Kissing Booth is a movie full of so many moral education which is perfect for people analyze the movie, perhaps in the aspect of characterization and storyline whether it's the main character or the plot of the film.

2. The Kissing Booth movie can also be used as a material in the High School students since it is a good example how to use slang in daily life.

3. To compare the subtitle of The Kissing Booth movie in the form of $\mathrm{CD}$ with the one that is shown in television.

\section{References}

Andersson, Lars

and

Trudgil

1 ,

Peter.

1990.

Bad

Language (Penguin books: Language and Linguistic). USA: Penguin Group Incorporated.

Bryman, A. 2008a. 'The End of The Paradigm Wars?', in Alasuutari, P.,Bickman, L., and Brannen, J. (eds.) The Sage Handbook of Social Research

Methods, London, Sage.

Chomsky, Noam. 1968. Language and Mind. UK: Cambridge University Press.

Claire, Elizabeth. 1998. Dangerous English 2000. USA: Delta Publishing Company.

Holmes, Janet. 2001. An Introduction to Sociolinguistics. London: Longman.

McGuire, Susan Bassnett. 1991. Translation Studies (New Accents). London: Routledge.

Partridge, Eric. 2004. Slang: Today and Yesterday. London: Routledge and Kegan Paul Ltd.
Language and Literature, Masaryk University.

Yanchun, Zhou, and Yanhong Fan. 2013. A Sociolinguistic Study of American Slang. Changchun: Changchun University of Science and Technology.

Zuckermann Ghil'ad. 2003. Language Contact and Lexical Enrichment in Israeli Hebrew. New York: PALGRAVE MACMILLAN. 
Veronika Burdová, Bc. 2009. Student Slang. Brno:

Faculty of Education, Department of English 